Escaping the subject-based class : A Finnish case study of developing transversal competencies in a transdisciplinary course

\title{
Eronen, Lasse
}

2019

Eronen , L , Kokko , S \& Sormunen , K 2019 , ' Escaping the subject-based class : A Finnish case study of developing transversal competencies in a transdisciplinary course ' , The Curriculum journal , vol. 30 , no. 3 , pp. 264-278 . https://doi.org/10.1080/09585176.2019.1568271

http://hdl.handle.net/10138/317925

https://doi.org/10.1080/09585176.2019.1568271

unspecified

acceptedVersion

Downloaded from Helda, University of Helsinki institutional repository.

This is an electronic reprint of the original article.

This reprint may differ from the original in pagination and typographic detail.

Please cite the original version. 


\title{
Escaping the subject-based class: A Finnish case study of developing transversal competencies in a transdisciplinary course
}

\author{
Lasse Eronen ${ }^{a}$, Sirpa Kokko ${ }^{\mathrm{b}} \&$ Kari Sormunen ${ }^{\mathrm{a}}$ \\ ${ }^{a}$ School of Applied Educational Science and Teacher Education, University of Eastern \\ Finland, Joensuu, Finland; ${ }^{b}$ Department of Education, University of Helsinki, Finland
}

\section{Introduction}

The global discussion concerning the school of the future has focused on 21 st century skills and competencies (cf., Flynn, 2014). The overall thinking emphasizes that active citizenship requires a command of a range of knowledge and skills as well as competence in combining these. The European Union (EU) governments have included teaching and learning of key competencies as part of their lifelong learning strategies. These include communication and science-based skills as well as generic skills such as learning to learn and social and civic, cultural and entrepreneurship competencies. (EU, 2006.) Similar approaches to include the transversal competencies that will be needed in the future can be found in educational policies from other parts of the world (UNESCO 2015). Often, it takes time to implement the pedagogical changes in practice since both the teachers and students may be inclined to continue with the long-lived practices. This article introduces students' views of a project-based course, the aim of which was to develop the Finnish eighth grade students' transversal competencies without defining the specific subject-based content to be learnt.

The project task of the course was to create an escape room which the school's other students would use. An escape room, also known as an "escape game", is a physical adventure game in which players solve a series of puzzles and riddles using clues, hints, and strategy to complete the objectives at hand. Players are given a time 
limit within which to unveil the secret plot, which is hidden within the rooms. When designing an escape room in teams, the students developed many competencies, which will be outlined in the article.

According to Finegold and Notabartolo (2010), the main reason for emphasizing transversal competence is that most new jobs in developed nations are in the service and information sectors, which require high levels of general skills. Ananiadou and Claro (2009) state that the acquisition of these competencies is as important to students' futures as successful employees that they must be incorporated into the national education standards enforced and evaluated by governments.

In many European countries, the push to incorporate the teaching of $21^{\text {st }}$ century skills has been enforced by educational reforms (Gordon et al., 2009). These have included new and more-integrative approaches to teaching and learning. The longlasting discipline-based curricula have been challenged by requirements for more holistic approaches which are called multidisciplinary, interdisciplinary, and transdisciplinary (Drake \& Burns, 2004), referring to teaching and learning that focuses on a common 'real-life' theme instead of on a certain knowledge area of each school subject. However, the integrative approach is criticised by many researchers especially if understood as a way to arrange the whole education without developing content knowledge in different areas (Hattie \& Donoghue, 2016; McPhail, 2018; Young 2013). Hattie and Donoghue (2016) argue that learning strategies should be an integral part of all teaching and learning, instead of arranging separate courses to learn them.

In 2014, the Finnish National Board of Education (FNBE, 2016) launched a new core curriculum with the aim of developing learning and teaching at Finnish comprehensive schools to meet the requirements of the future. The national core 
curriculum consists of many chapters discussing the values, learning environments and pedagogical approaches, as well as the goals and contents of each subject in each grade. It follows both the curriculum tradition, with emphasis on learning, and the didactic tradition, which is more discipline-based. The national core curriculum provides the basis for the more detailed locally constructed curricula (Pietarinen, Pyhältö \& Soini, 2017). A substantial weight was given to transversal competence areas "that cross the boundaries of and link different fields of knowledge and skills" (FNBE 2016, p. 21). The key transversal competence areas cover aspects of learning, culture, interaction, taking care of oneself, daily life, multiliteracy, ICT, entrepreneurship, participation and sustainability (Lonka, 2018). These are introduced thoroughly in the national core curriculum (FNBE, 2016, pp. 21-26). Although "each subject builds the pupil's competence through the contents and methods typical of its field of knowledge" (FNBE, 2016, p. 21), the role of transversal competencies as part of each school subject is made explicit in the curriculum.

To reach the targets of transversal competence on one hand, and the targets of different school subjects on the other, the teaching and learning methods were revised. Integrative instruction and multidisciplinary learning modules are nominated as ways to support comprehensive basic education for the students to "see the relationships and interdependencies of the phenomena to be studied" (FNBE, 2016, p. 32). The curriculum leaves the manner and duration of integrative instruction to be decided locally but gives examples of the ways they could be arranged. Moreover, it is required that a multidisciplinary learning module is included in the studies every year.

Research concerning the implementation and achievement of the 21 st century curricula targets has often concentrated on the teachers' or other stakeholders' views and approaches (van de Oudeweetering \& Voogt, 2018; Pietarinen et al., 2017). However, 
listening to the students' voices is crucial to finding out how the implemented activities are received and experienced (Kokko, Eronen \& Sormunen, 2015; McPhail, 2016). This paper focuses on the students' perspectives in a course developed by a Finnish teacher to achieve the targets of developing their transversal competence through integrative instruction. This optional science course for the Finnish eighth grade students in spring 2017 was intended to try out new approaches to teaching and learning before the national core curriculum for basic education in Finland came into force (2016-2018). The course was arranged so that the students took the main responsibility for the contents and methods of learning in a project-based manner. The research purpose was to find out what transversal competencies the students developed and how they experienced studying in courses of this kind.

\section{Approaches to integrated curriculum}

Drake and Burns (2004) discuss various categories of the integrative approach in teaching. They comment that this has been a topic of discussion since the turn of the 20th century. They arranged the approaches to integration under three categories: multidisciplinary, interdisciplinary, and transdisciplinary. According to them, the multidisciplinary approach may integrate different disciplines in many ways around a common theme, or a chosen theme is fused into the teaching of different disciplines, or it can be arranged in the form of service learning in the community. The interdisciplinary approach refers to organizing the curriculum around common learning across disciplines.

The transdisciplinary approach does not take the disciplines as the starting point, but instead, it is based on the students' questions and their concerns about developing life skills in real-life contexts (Bostan, 2015). In this approach, the students apply interdisciplinary and disciplinary skills in project-based learning, which starts with 
selecting a topic of the students are interested in. The teacher both helps them to generate questions to explore the topic and provides the resources for the work. The students share their work with others in a culminating activity, and they also review and evaluate the project. Another form of the transdisciplinary approach is negotiating the curriculum so that the students' questions form the basis of the curriculum (Drake \& Burns, 2004).

All these approaches are being developed and tested in educational settings around the world. Helmane and Briška (2017) analysed the concepts of integrated learning and state that educators need to be aware of the type of integration to reach the educational goals effectively. They conclude that the transdisciplinary approach is apparently the most productive for the development of students' competencies and life skills.

Transdisciplinary approach has proved out to fit well in the STEAM (science, technology, engineering, art and mathematics) instruction which is based on integrating the STEAM subjects in problem-based learning through innovation, creativity, critical thinking, effective communication, and student-centric collaboration (Connor, Karmokar, \& Whittington, 2015). Herro, Quigley and Dsouza (2016) conducted a case study with two STEAM teachers using a transdisciplinary approach in the comprehensive education in the USA. They conclude that the teachers found this approach challenging since it demanded that they change their role from teaching to allowing more student choice. However, they also found this approach to be engaging and motivating for both the teachers and the students.

Another study by Quigley and Herro (2016) explored the enactment of teaching practices by 21 middle school teachers after completing intensive STEAM professional development. Although some teachers in this study were successful in using 
transdisciplinary approach, most of them had difficulties with it. The researchers found this to be due to the background of single content area training and standards-driven curriculum and suggest supporting teachers in interdisciplinary and multidisciplinary teaching practices prior to the introduction of transdisciplinary approaches. Flogie and Aberšek (2015) noted an increase in student motivation in their study on the transdisciplinary approach to STEM (science, technology, engineering and mathematics) instruction in Slovenian comprehensive schools. They emphasized the role of the teachers as the main actors in delivering innovative pedagogical change. The transdisciplinary approach requires the teachers to rethink their role to become more of a mentor and facilitator than a knowledge transmitter. This approach also involves thinking and arranging the learning environments in new ways, to encourage student collaboration (Byers, Imms \& Hartnell-Young, 2018).

Notwithstanding the widely accepted idea of the need for more integrative approaches to school education, many researchers emphasize the value of and need for discipline-based teaching and learning (Young 2013; McPhail 2018). Young (2013) talks about the crisis in curriculum theory when the students' access to knowledge is not taken as a starting point. He criticizes the curriculum approach that is based on pupils' immediate interests since it may be too tight to define their everyday experiences in narrow contexts. Another argument suggests that disciplines are the main source of the deeper content which is essential for a cognitive advancement to move beyond common sense (McPhail, 2018). According to Hattie and Donoghue (2016) developing generic skills is subject specific; learning strategies developed in one subject area are not applicable to the others.

Finnish schools and teachers have considerable freedom to choose their approaches. However, in public discussion, there are also doubts about the Finnish 
teachers' ability and willingness to implement new pedagogical thinking (Pietarinen et al., 2017). The course studied for this paper was developed by an enthusiastic Finnish teacher who was convinced of the benefits of an integrative approach for acquiring $21 \mathrm{st}$ century skills. Although this optional course was offered within the category of science courses, the teacher had deliberately left the content open to be decided and constructed along the process, relying on the students' ability to find, adapt and develop information and skills required in different phases of the project.

\section{The transdisciplinary approach in an optional course for Finnish eighth grade students}

The Finnish National Core curriculum for Basic Education 2014 (FNBE, 2016) has come into force gradually, starting with the primary level grades 1-6 (7 to 12-year-old pupils) in 2016, and continuing at the secondary level with grade seven (13-year-old students) in 2017, grade eight in 2018, and grade nine in 2019. The course for the Finnish eighth graders studied in this paper was organized in 2017 before the new curriculum for this age group had come into force. However, the school was following the national guidelines and had defined the transversal competence areas for each grade.

When discussing large-scale curriculum reform in Finland, Pietarinen et al. (2017) noted that building agency over reform requires the testing of new ideas with those who work at the grassroots level of schools. The teacher of the course studied in this paper wanted to develop new approaches in a pilot course. As a teacher of biology and geography, he advertised this optional course as science-based but did not specify the exact content beforehand. This way he followed the principles of transdisciplinary approach to teaching and learning which does not take the disciplines as a starting point (Bostan, 2015). However, he had decided that the practical task of the course would be 
to plan and build an escape room. The course lasted four months and was conducted as a 150-minute lesson once a week.

At the beginning of the course, the teacher was interviewed about his ideas and about his plans for the teaching and learning methods. It became clear that the teacher was determined about the importance of making the school a place where the students could decide what is meaningful to them now and in the future. He emphasized the idea of empowering the students so that they would devote themselves to learning things meaningful to them.

The teacher wanted to let the students engage in a spontaneous learning process, which would release their energy so that there would be no need for substantial efforts to motivate their learning. An important target for him was to let the various capacities of the students become visible and thus to support the self-esteem of those who often fail in the present school system. With project-based learning, he wanted to reduce the role of the school subjects to make room for developing other qualities competencies that the students would need in the future. In his ideas, the role of the teacher in projectbased learning was to support the learning process by asking relevant questions, rather than giving direct answers.

The assessment of the course was based on continuous feedback both from the teacher to the students and between students. The teacher was observing the student work and giving feedback along the project. However, he avoided interfering too much in the students' process but rather encouraged them to give feedback to each other. The feedback was verbal. The final grading of the course was pass/fail. The requirements for passing were active participation in the teamwork throughout the project and fulfilling the tasks of the course, such as participation in the final presentation of the escape room for a wider audience. All the participating students passed the course. 


\section{Research questions, the data and analysis}

Case study strategy (Gilham, 2010) was applied, as it is a suitable method for a situation in which little is known about how students experience what is going on in a classroom. In this study concerning the transdisciplinary approach to teaching and learning, case study provides the perspectives of those involved. The purpose was to explore what the students thought they had learnt in the course and how they had experienced the transdisciplinary approach. The research questions were:

(1) What competencies did the students develop in a transdisciplinary course?

(2) What were the students' experiences with the transdisciplinary course?

The data were gathered from the eighth-grade students (14-15 years old; 12 boys and seven girls) by the open-ended questionnaires before and after the course, and by interviewing some of the students after the project. All 19 students who participated in the course responded to the pre- and post-questionnaires and, after the project was finished, five randomly-selected boys and five randomly-selected girls participated in an in-depth interview conducted by two of the researchers. Both the questionnaires and the interview focused on 1) the students' motivation to participate in the course, 2) their experiences of the course in general, 3) their learning, 4) their experiences of teamwork and their own role in it, and 5) their views about the purpose of integrative instruction stated by the national core curriculum:

\footnotetext{
Examination of wholes and exploratory work periods that link different fields of knowledge guide the pupils to apply their knowledge and produce experiences of participation in the communal building of knowledge. This allows the pupils to perceive the significance of topics they learn at school for their own life and community, and for the society and humankind (FNBE, 2016, p. 32).
} 
Furthermore, the interview dealt with the students' experiences about how their certain transversal competencies (see Table 1) were developed during the course, and their views about the role of the teacher in it. The length of the interviews varied from 17 to 40 minutes. All the interviews were audio-recorded and then transcribed for the analysis. The textual data of the pre- and post-questionnaires, and the interviews were gathered into a data file representing each student.

The analysis was based on qualitative content analysis (see, e.g., Schreier, 2014) which in this case was inductive in its nature (Vaismoradi, Turunen \& Bondas, 2013; Hsieh \& Shannon, 2005). First, all the data were read through by two of the researchers to find the emerging categories which would form the basis of the analysis. After that, the thematic texts from both the questionnaires and interviews were classified according to these categories. The analysis continued by creating sub-categories representing more detailed themes. After agreeing on the trial coding, one of the researchers continued coding the whole data set and he slightly modified the coding frame based on evaluative discussions with other two researchers (cf. Schreier, 2014). Finally, the main categories were generalized to find answers to the research questions. The analysis was made against the targets of generic skills, the competencies that were defined in the school curriculum for this age group, following the guidelines of the National Core Curriculum for Basic Education. These were T1 Thinking and learning to learn; T2 Cultural competence, interaction and self-expression; T3 Taking care of oneself and managing daily life; T4 Multiliteracy; T5 ICT competence; T6 Working life competence and entrepreneurship; T7 Participation involvement, building the sustainable future. All these categories had more targets than are specific for this age group. For the analysis, one target representing each competence category was chosen as the basis of the analysis shown in Table 1. However, two targets formed the basis of analysis with 
category $\mathrm{T} 1$, which consists of two aspects. In the questionnaires and interviews, the students were asked how they had acquired the competencies that were specifically addressed to eighth grade in the school curriculum.

Table 1. Categories of the competence areas. [see in the end]

All the data gathering, i.e., the questionnaires and the interviews, was carried out in Finnish. With the purpose of making the idea of the citation clear, the researchers translated the English citations presented in this paper. The citations are anonymous but are distinguished by the code number (e.g., \#11) that each student was given in the analysis, to show the variety of the students represented.

\section{Findings}

\section{Developing transversal competencies}

According to the interviews, many aspects of the targets of learning transversal competencies were covered. All the students responded that they had acquired the T1 generic skills, Thinking and learning to learn. They learnt how to find new, creative and alternative solutions through teamwork and in solving the problems. They learnt to develop their learning strategies consciously by taking part in the teamwork and by working independently.

When working in the team, thinking of the ideas that the team provided, they gave me new ideas concerning my own thinking. And this could lead to something other than would have been the case with only my own thoughts. (\#11)

The school curriculum for eighth grade on the T2 target, Cultural competence, interaction and expression, emphasized interaction and expression over cultural competence. In this project, the target was mainly gained through teamwork which 
required each participant to learn to express their ideas constructively. The students talked about the need to learn to justify their views convincingly and to learn to listen and consider the perspectives of the others.

The students learnt to take responsibility for themselves and the others which was a specific target of T3 for their grade in the school curriculum. This was shown in their commitment to get the escape room ready by taking responsibility for their own input, such as the following:

I needed to take responsibility for my own work but also from the others in order to get the assignment done. (\#11)

Sometimes I needed to work alone with some of the stuff, and there I needed to take responsibility. (\#12)

They were committed to the joint targets and took responsibility for meeting them as a team. The respective teams were also crucial in how T4, Multiliteracy, was developed. In some teams, there was a need to find multiple solutions for expressing oneself, whilst in others, the mutual understanding was more straightforward. The students talked about having learnt to use different ways to express themselves with different people in their respective teams.

In designing the tasks for the escape room, some teams utilized T5, ICT competence, for example in coding the locks or giving hints about the problems to be solved. They talked about finding creative solutions to their problems and learning new skills, such as explained in the following:

I would say that our hint (in the escape room) was rather creative. We learnt many things, such as combining a piano and a computer. When coding this combination, I really needed to do something. (\#14)

The targets of T6, Working life competence and entrepreneurship, concern the ability to act in new and unpredictable situations. This target seemed to be well achieved in this 
project in which everything was new. The students were compelled to face unpredictable situations, create problems to be solved in the escape room and solve the problems themselves. They said they had to use their imagination and express themselves in new ways.

Participation and influence were central in the school's curriculum on target T7. The students reflected on their actions in the group critically. They learnt to find and develop versatile solutions to the problems. They learnt self-management skills in planning and scheduling their work.

Critical reflection to our own activities; we should probably begin a bit earlier, for example by scheduling and thinking of more varied solutions. And communication with the others; we had these debates and that kind of discussions about which way would be better. (\#15)

Although the course did not define the disciplines that were to be integrated, as researchers, we were interested to find out how the students connected their learning to the school subjects. Thus, they were asked what subject-based skills and knowledge they thought they had acquired during the project. On the whole, they didn't recognize specific subject contents, or these were referred to superficially. Mainly, they recognized learning mathematics and crafts. For example, learning mathematics was recognized in measuring the walls of the escape room, and in a more challenging task related to designing secret codes. Crafts were learnt when constructing the walls and different parts of the escape room. Sometimes, the learning connected to specific disciplines was weak, such as carrying things around as an example of physical education.

\section{Developing teamwork skills}

The analysis revealed that the nature of teamwork was crucial in project-based learning. 
Since the students talked about this topic a lot, it was decided that it should be looked at in more detail. In general, all the activities and outcomes seemed to depend on how the teamwork was carried out. Teamwork skills proved to be essential generic skills to be acquired, and the analysis revealed three categories of the meanings of teamwork. The first was learning to express and argue one's own opinions constructively, and to consider differing opinions.

When working in teams, you could not just nullify the others' thoughts. And if you wanted the others to consider your ideas, you couldn't just say that here is my idea and it's the best, and let's do it. (\#15)

The second category consisted of taking responsibility for the teamwork, sharing the duties and the responsibilities in the team. Many students commented on the importance of recognizing different roles in the team and utilizing them to reach the team's goals. There was a general understanding of the importance of someone taking the role of the team leader, to ensure that the teamwork would reach its goal, although equal participation and initiative were also emphasized.

A good team requires a good and thoughtful leader who recognizes both the good things and the faults. Then there is a need for a couple of people who bring good ideas to the leader who justifies whether the ideas are good or not. And then we need the workers who work according to the ideas and instructions. And maybe someone to do the final touch following the ideas of the three former participants mentioned. And finally, the leader needs to see if the outcome is good or if something should be changed. I think this might be a good plan. (\#13)

The third category included aspects of evaluating the practices of teamwork and developing them further. For fruitful cooperation, it is essential that the team members enjoy their participation and do not feel that it is compulsory. The importance of good planning and continuity was raised. One student said that she/he had learnt what was 
meant by long-lasting teamwork. "It is not a one-hour thing. It means using a lot of time, continuing and talking a lot." (\#14)

Most students expressed the view that good teamwork requires the commitment of each participant, which was not always the case. They raised the problem of unequal participation which was seen as being unfair. Obviously, this aspect needs careful consideration from both the teachers and the students, especially when starting the teamwork.

\section{Experiences of a transdisciplinary course}

When asked about their experiences of taking part in the course, most of the students were happy about the opportunity to attend a course that was different from the ordinary schoolwork and thus offered a much-appreciated change. Many of them commented that the course was relaxed, nice, cool and exciting. The positive experiences related to avoiding the boredom they suggested is often connected to normal schoolwork.

I think it was just fun and brought change and ... you did not just need to sit at a desk and listen to the teacher. You had a chance to do things more creatively. (\#16)

The different teaching and learning methods were commented on as contrasting the more common teacher-centred practices. The students were given considerable responsibility over their activities and learning which was appreciated since it provided them with the opportunity for creativity and autonomy. The tangible results of this project were also rewarding and made it possible to see the real-life results of the group work.

The students had experienced the role of the teacher as being very different from ordinary school practices. The teacher had provided the main guidelines and timeframes for the work but otherwise the students had a free hand to carry out the course tasks. 
When required, the teacher guided the learning, for example by helping in improving the ideation and putting things together. He helped the teamwork by offering encouragement and guidance. His role was also to provide the materials and to take care of the general arrangements for the learning.

The teacher really let us work independently but he also kind of kept the process together and tried to keep it on schedule. (\#12)

The students were asked what they thought about this integrative teaching in relation to the curriculum guidelines that they were shown (presented earlier in the method section). Most of them appreciated these perspectives and reflected on the guidelines against their own experiences about the course, commenting that this kind of working helped to develop the competence that they would need in everyday life and in the future work life. Furthermore, they paid attention to the opportunity to combine the content areas of different disciplines.

It was combing different knowledge areas, everyone had different knowledge, and then we adapted all the knowledge and worked together. And so, they will be useful in the future life. (\#11)

The positive aspects that were raised brought up recognition and appreciation of multiple aspects, such as the peers' knowledge and sharing knowhow with them, and collaborative work with the peers when thinking, planning and discussing together how to solve the problems. The relevance and utility of these aspects to future work life and the possibility to adapt them in different contexts was also recognized.

\section{Discussion}

The transdisciplinary approach has proved out to be productive for the development of life skills (Helmane \& Briška, 2017). In this study, many students felt that this kind of 
learning was beneficial since they acquired the competencies that they would need later in their lives. Nonetheless, when the students were asked in general about what they had learned, many commented that they had not learnt much. These comments referred to the discipline-based knowledge, revealing that these eight-graders had adapted the idea of school learning as acquisition of specific subject content. Instead, they described how they had acquired skills through teamwork, problem solving and expression of one's views and opinions, aspects that they did not really connect with the idea of things to be learnt at school.

Although the students adapted the knowledge gained in various school subjects in designing and making the escape room, their knowhow during the project, they failed to see the connections to the academic content in this project. Obviously, the approach in this course was very different from the structured subject-based learning and teaching that they were more used to (Hattie \& Donohough, 2016). The course introduced in this paper was experimental and left open the subject-based content to be adapted and learnt. However, utilizing the epistemic basis of certain subject areas is an option in integrative educational approaches worth keeping in mind if the purpose is to deepen knowhow on certain areas and adopt this specific knowhow in new situations.

Many researchers have pointed out the importance of the teacher's ability and willingness to implement new pedagogical approaches as a prerequisite to the curriculum reforms to be realized in school practices (Herro, Quigley \& Dsouza, 2016). In the study presented here, this prerequisite was met, and the teacher was willing to arrange a pilot course in which the target was to acquire transversal competencies, instead of the specific content of different school subjects. The teacher was ready to change his role as a teacher and to allow the students to have more choice, an aspect that has proved to be demanding for many teachers with integrative approaches (cf. 
Quigley \& Herro, 2016). For an educator, it is essential to be aware of the many ways of arranging integrative learning, and to choose the best to meet their educational goals (Drake \& Burns, 2004; Helmane \& Briška, 2017).

The Finnish National Core Curriculum for Basic Education (FNBE, 2014) requires the schools to arrange an integrative learning module for the students at least once every year. However, discipline-based teaching and learning various school subjects are still essential in this curriculum. This implies that the curriculum tries to balance between different pedagogical approaches and recognize the benefits of discipline-based learning which some researchers remind us about (cf. McPhail 2018; Venville, Rennie \& Wallace, 2012; Young 2013).

For the integrative approach in teaching and learning to be successful, it is important to overcome the cultural barriers and practical challenges of school work (Lam, Alviar-Martin, Adler \& Sim, 2013). In the discussions about the arrangements of integrative teaching and learning, co-teaching is often taken as a starting point. Without doubt, many benefits arise from the teachers' cooperation, such as sharing ideas relating to the expanded use of teaching methods, expanded ideation, and shared responsibility for the teaching arrangements (cf. an extensive review by Vangrieken, Dochy, Raes \& Kyndt, 2015). We acknowledge the limitations of the research design and methods, such as the self-reporting by the teacher and the students, for any wider conclusions. However, the case study presented in this paper revealed that even one teacher acting alone could adapt integrative approaches in arranging the courses. This implies that there could be more flexibility in thinking about the ways to introduce integrative teaching.

\section{Conclusion}

The integrative course presented in this study was about students constructing an escape 
room and, symbolically, escaping the subject-based school. The purpose was to provide a learning environment for the students to acquire $21^{\text {st }}$ century skills through a transdisciplinary approach to teaching and learning. The findings revealed that the students appreciated the opportunity to take responsibility for their own learning, and that they valued acquiring transversal competencies. The students' teamwork had a crucial impact on their learning experience. Since good teamwork requires committed participants, it is essential to concentrate on motivating the students and supporting them in all the phases. The timeframe of the integrative approach needs careful consideration; it was felt that the project-based learning process in this course was successful because it lasted long enough for the students to get used to the work method and to achieve the goals of the project.

The transdisciplinary approach provided much appreciated change to the more traditional discipline-based schooling that these eighth graders were used to. However, they did not recognize having learnt much discipline-based academic content. We share the view that teaching and learning of $21^{\text {st }}$ century skills is essential in present-day education. This can be implemented through different integrative approaches. The transdisciplinary approach adopted in this study is an example of how even one teacher can develop and test new approaches creatively. However, the acquisition of $21^{\text {st }}$ century skills is not only about integrative projects but also a target to be kept in mind in various school subjects; developing subject-based knowledge in these fields forms a good basis for adapting them in real-life contexts. This case study was conducted with one school class of Finnish eighth grade students and thus has limited capacities for generalization. However, it brings out the views of students, something which should be kept in mind when reforming the curriculum. 


\section{Acknowledgements}

We thank the enthusiastic biology and geography teacher for inviting us to follow his innovative course and for sharing his ideas with us. We also thank the open-minded eighth graders who expressed their views and experiences in the interviews and in the questionnaires.

\section{References}

Ananiadou, K., \& Claro, M. (2009). 21 st century skills and competencies for new millennium learners in OECD countries. OECD Education Working Papers, No. 41. OECD

Publishing. http://www.oecd.org/officialdocuments/publicdisplaydocumentpdf/ ?cote $=\mathrm{EDU} / \mathrm{WKP}(2009) 20 \&$ doclanguage $=$ en $($ Accessed 12 January, 2018.)

Bostan, C.-G. (2015). Inter- and transdisciplinary issues present in the school curriculum. Procedia - Social and Behavioral Sciences, 180, 489-496.

Byers, T., Imms, W. \& Hartnell-Young, E. (2018). Comparative analysis of the impact of traditional versus innovative learning environment on student attitudes and learning outcomes. Studies in Educational Evaluation, 58, 167-177.

Connor, A.M., Karmokar, S. \& Whittington, C. (2015). From STEM to STEAM: Strategies for Enhancing Engineering \& Technology Education. International Journal of Engineering Pedagogy, 5, 37-47.

Drake, S. \& Burns, R. (2004). Meeting Standards through Integrated Curriculum. Alexandria, VA: Association for Supervision \& Curriculum Development. EU. (2006). Recommendations of the European Parliament and of the Council of 18 December 2006 on Key Competences for Lifelong Learning (2006/962/EC). Official Journal of the European Union, 30.12.2006. http://eurlex.europa.eu/legal-content/EN/TXT/?uri=LEGISSUM\%3Ac11090 (Accessed 12 January, 2018.)

Finegold, D., \& Notabartolo, A. S. (2010). 21st-century competencies and their impact: An interdisciplinary literature review. William and Flora Hewlett Foundation. https://www.hewlett.org/library/21st-century-competencies-impactinterdisciplinary-literature-review/ (Accessed 12 January, 2018.) 
Flogie, A. \& Aberšek. (2015). Transdisciplinary approach of science, technology, engineering and mathematics education. Journal of Baltic Science Education, 14, 779-790.

Flynn, T. (2014). Do They Have What It Takes? A Review of the Literature on Knowledge, Competencies, and Skills Necessary for Twenty-First-Century Public Relations Practitioners in Canada. Canadian Journal of Communication, $39,361-384$.

FNBE (2016). National Core Curriculum for Basic Education 2014. Helsinki: Finnish National Board of Education.

Gilham, B. (2010). Case Study Methods. London: Bloomsbury.

Gordon, J., Halasz, G., Krawczyk, M., Leney, T., Michel, A., Pepper, D., Putkiewitcz, E. \& Wisniewski, J. (2009). Key Competences in Europe: Opening Doors for Lifelong Learners across the School Curriculum and Teacher Education. CASE Network Report, No. 87. Warsaw: Center for Social and Economic Research. https://www.econstor.eu/bitstream/10419/87621/1/613705459.pdf (Accessed 11 January, 2018.)

Hattie, J.A.C. \& Donoghue, G.M. (2016). Learning strategies: a synthesis and conceptual model. npj Science of Learning, 1, article 16013.

Helmane, I. \& Briška, I. (2017). What is Developing Integrated or Interdisciplinary or Multidisciplinary or Transdisciplinary Education in School? Signum Temporis, 9, 7-15.

Herro, D., Quigley, C. \& Dsouza, N. (2016). STEAM Enacted: A Case Study Exploring Middle School Teachers Implementing STEAM Instructional Practices. Journal of Computers in Mathematics and Science Teaching, 35, 319-342.

Hsieh, H.-F. \& Shannon, S.E. (2005). Three Approaches to Qualitative Content Analysis. Qualitative Health Research, 15, 1277-1288.

Kokko, S., Eronen, L. \& Sormunen, K. (2015). Crafting Maths: Exploring Mathematics Learning through Crafts. Design and Technology Education: An International Journal, 20, 22-31.

Lam, C.C., Alviar-Martin, T., Adler, S.A. \& Sim, J. (2013). Curriculum integration in Singapore: Teachers' perspectives and practice. Teaching and Teacher Education, 31, 23-3

Lonka, K. (2018). Phenomenal Learning from Finland. Helsinki: Edita. 
McPhail, G. (2018). Curriculum integration in the senior secondary school: a case study in a national assessment context. Journal of Curriculum Studies, 50, 56-76.

McPhail, J. (2016). From aspirations to practice: curriculum challenges for a new 'twenty-first-century' secondary school. The Curriculum Journal, 27, 518-537.

Pietarinen, J., Pyhältö, K. \& Soini, T. (2017). Large-scale curriculum reform in Finland - exploring the interrelation between implementation strategy, the function of the reform, and curriculum coherence. The Curriculum Journal, 28, 22-40.

Quigley, C. \& Herro, D. (2016). "Finding the Joy in the Unknown”: Implementation of STEAM Teaching Practices in Middle School Science and Math Classrooms. Journal of Science Education and Technology, 25, 410-426.

Schreier, M. (2014). Qualitative Content Analysis. In U. Flick (Ed.) The SAGE Handbook of Qualitative Data Analysis (pp. 170-183). London: SAGE.

UNESCO. 2015. Transversal Competencies in Education Policy and Practice (Phase I). Asia-Pacific Education Research Institutes Network (ERI-NET). Paris and Bangkok, UNESCO. http://unesdoc. unesco.org/images/0023/002319/231907E.pdf (Accessed 12 October, 2016.)

Vaismoradi, M., Turunen, H. \& Bondas, T. (2013) Content analysis and thematic analysis: Implications for conducting a qualitative descriptive study. Nursing \& Health Sciences, 15, 398-405.

Van de Oudeweetering, K. \& Voogt, J. (2018). Teachers' conceptualization and enactment of twenty-first century competences: exploring dimensions for new curricula. The Curriculum Journal, 29, 116-133.

Vangrieken, K., Dochy, F., Raes, E. \& Kyndt, E. (2015). Teacher collaboration: A systematic review. Educational Research Review, 15, 17-40.

Venville, G., Rennie, L.J. \& Wallace, J. (2012). Curriculum Integration: Challenging the Assumption of School Science as Powerful Knowledge. In B.J. Fraser, K. Tobin, C.J. McRobbie (Eds.), International Handbook of Science Education (pp. 737-749). Dordrecht: Springer.

Weinberg, A.E. McMeeking, L.B.S. (2017). Toward Meaningful Interdisciplinary Education: High School Teachers' Views of Mathematics and Science Integration. School Science and Mathematics, 117, 204-211.

Young, M. (2013). Overcoming the crisis in curriculum theory: a knowledge-based approach. Journal of Curriculum Studies, 45, 101-118. 
Table 1. Categories of the competence areas.

\begin{tabular}{|c|c|c|}
\hline $\begin{array}{l}\text { Transversal competence } \\
\text { area in the Finnish } \\
\text { National Core Curriculum }\end{array}$ & $\begin{array}{l}\text { School specific competencies } \\
\text { for the eighth grade which } \\
\text { were discussed during the } \\
\text { interview }\end{array}$ & $\begin{array}{l}\text { Sub-categories emerged in the } \\
\text { content analysis }\end{array}$ \\
\hline $\begin{array}{l}\text { Thinking and learning to } \\
\text { learn (T1) }\end{array}$ & $\begin{array}{l}\text { "Finding new opportunities } \\
\text { and creative solutions." }\end{array}$ & $\begin{array}{l}\text { Team negotiation skills } \\
\text { Creating escape room problems }\end{array}$ \\
\hline $\begin{array}{l}\text { Thinking and learning to } \\
\text { learn (T1) }\end{array}$ & $\begin{array}{l}\text { "Learning to consciously } \\
\text { develop the learning and } \\
\text { studying methods." }\end{array}$ & $\begin{array}{l}\text { Reflections on own team working } \\
\text { skills } \\
\text { Developing new approaches to } \\
\text { working } \\
\text { Developing independent working } \\
\text { skills }\end{array}$ \\
\hline $\begin{array}{l}\text { Cultural competence, } \\
\text { interaction and self- } \\
\text { expression (T2) }\end{array}$ & $\begin{array}{l}\text { "Learning to express opinions } \\
\text { constructively." }\end{array}$ & $\begin{array}{l}\text { Sharing own opinions } \\
\text { Activating the others } \\
\text { Developing the escape room } \\
\text { problems } \\
\text { Social interaction, discussion and } \\
\text { listening } \\
\text { Problem solving }\end{array}$ \\
\hline $\begin{array}{l}\text { Taking care of oneself and } \\
\text { managing daily life (T3) }\end{array}$ & $\begin{array}{l}\text { "Learning to take } \\
\text { responsibility of myself and } \\
\text { the others." }\end{array}$ & $\begin{array}{l}\text { Responsibility of meeting the targets } \\
\text { of the project } \\
\text { Commitment to get the escape room } \\
\text { ready } \\
\text { Responsibility of one's own input } \\
\text { Commitment to the joint targets }\end{array}$ \\
\hline Multiliteracy (T4) & $\begin{array}{l}\text { "Learning to express my } \\
\text { views in many different } \\
\text { ways." }\end{array}$ & $\begin{array}{l}\text { Writing and speaking } \\
\text { Reflecting on the meaning of } \\
\text { different kinds of groups to one's } \\
\text { expression } \\
\text { Learning to express oneself } \\
\text { differently to different people }\end{array}$ \\
\hline ICT competence (T5) & $\begin{array}{l}\text { "Learning to work with ICT } \\
\text { constructively." }\end{array}$ & $\begin{array}{l}\text { Creating the ICT-based hints for } \\
\text { escaping the room } \\
\text { Coding the key for the room lock }\end{array}$ \\
\hline $\begin{array}{l}\text { Working life competence } \\
\text { and entrepreneurship (T6) }\end{array}$ & $\begin{array}{l}\text { "Learning such competencies } \\
\text { and skills that are required in } \\
\text { new and different situation." }\end{array}$ & $\begin{array}{l}\text { The situation was new and compelled } \\
\text { them to act in a new way } \\
\text { When creating the hints to the escape } \\
\text { room they needed to develop new } \\
\text { competencies } \\
\text { Developed self-expression } \\
\text { New viewpoints to things } \\
\text { Using imagination }\end{array}$ \\
\hline $\begin{array}{l}\text { Participation involvement, } \\
\text { building the sustainable } \\
\text { future (T7) }\end{array}$ & $\begin{array}{l}\text { "Learning to estimate my } \\
\text { working habits and to develop } \\
\text { them." }\end{array}$ & $\begin{array}{l}\text { Developing solutions to problems } \\
\text { Critical reflection on the actions } \\
\text { Procedures developed in group work } \\
\text { Developing new approaches to } \\
\text { solutions } \\
\text { Learning time management }\end{array}$ \\
\hline
\end{tabular}

